\title{
A new paleofloristic assemblage from the Cuyana Basin (Agua de los Pajaritos depocenter), Argentina and its paleobiogeographic and paleoenvironmental implications
}

\author{
Juan M. Drovandi a,b,c,*, Gustavo A. Correa ${ }^{\text {a,b,c }}$, Josefina Bodnar ${ }^{\text {b,d }}$, Carina E. Colombi ${ }^{\text {a, b, c }}$, \\ Eliana P. Coturel ${ }^{\mathrm{b}, \mathrm{d}}$, Eduardo M. Morel ${ }^{\mathrm{d}}$ \\ ${ }^{a}$ Instituto y Museo de Ciencias Naturales, Área Paleontología de Vertebrados, Universidad Nacional de San Juan, 5400, San Juan, San Juan, Argentina \\ ${ }^{\mathrm{b}}$ Consejo Nacional de Investigaciones Científicas y Técnicas (CONICET), Argentina

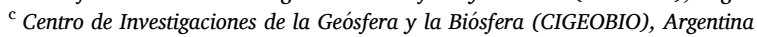 \\ ${ }^{\mathrm{d}}$ División Paleobotánica, Facultad de Ciencias Naturales y Museo, Paseo del Bosque S/N, 1900, La Plata, Argentina
}

\section{A R T I C L E I N F O}

\section{Keywords:}

Middle-triassic

Cuyana basin

Monina formation

Paleofloristic record

\begin{abstract}
A B S T R A C T
In this study, we examined the first paleofloristic record for the Monina Formation, Middle Triassic, Agua de los Pajaritos depocenter, Cuyana Basin, San Juan Province, Argentina. The paleoflora includes representatives of Isoetales, Peltaspermales, and Coniferales in addition to some unidentified taxa classified as incertae sedis. The species determined, described, and compared were: Lepacyclotes sp.; Matatiella cf. roseta, Anderson and Anderson2003; Scytophyllum sp.; Cf. Rissikianthus; Protocircoporoxylon sp.; Cordaicarpus sp.; and Acevedoa cf. rastroensis (Arce and Lutz) Arce and Lutz 2014. In addition, a model is proposed to determine paleofloristic associations as well as reconstruction of the paleoenvironment based on the depositional architecture and the preservational mode of the paleofloristic remains.
\end{abstract}

\section{Introduction}

The Cuyana, Ischigualasto-Villa Unión, and Marayes-El Carrizal basins are part of a series of continental extensional basins that developed along the western margin of Gondwana during the early Mesozoic (e.g. Uliana et al., 1989; Ramos and Kay, 1991; López Gamundí, 1994; Spalletti, 1997, 2001). These basins provide a continuous record of the Triassic in Argentina and share many paleofloristic elements. The presence of these elements facilitated the generation of a chronographic and biostratigraphic linkage scheme for all lithostratigraphic units southwest of Gondwana (Spalletti et al., 1999).

In particular, the Cuyana (also known as Cuyo), Basin is notable for its abundant and diverse paleoflora, which form an important link between different depocenters in areas north and south of the basin. The taphofloras present in the north-western sector of the San Juan Province are distributed among three main depocenters (Rolleri and Criado Roque, 1968; Yrigoyen and Stover, 1970; Stipanicic, 1979): i) Rincón Blanco (Borrello and Cuerda, 1965) and ii) Agua de los Pajaritos (= Hilario) (Stipanicic, 1972, 1979), both located on the western slope of the Sierra del Tontal, and iii) Barreal (Groeber and Stipanicic, 1953) located along the eastern flank of the Los Patos river valley (Fig. 1). These depocenters correspond to the Rincón Blanco (Borrello and Cuerda, 1965) and Sorocayense (Mésigos, 1953) groups, which provide abundant paleofloristic records throughout the Middle Triassic/early Late Triassic (e.g. Frenguelli, 1948; Stipanicic and Menéndez, 1949; Groeber and Stipanicic, 1953; Bonetti, 1963; Stipanicic and Bonetti, 1965; Stipanicic, 1972, 1979; Artabe et al., 1995a, 1998; Zamuner et al., 1999; Bodnar, 2010; Barrdo, 2012; Bodnar et al., 2019). The Sorocayense Group in the Agua de los Pajaritos depocenter has provided a wide variety of stratigraphic schemes since its discovery (Pozzo, 1948; Groeber and Stipanicic, 1953; Stipanicic, 1969, 1972, 1979; Baraldo and Guerstein, 1984; Spalletti et al., 1999, 2001; Stipanicic and Zavattieri, 2002; Zamora et al., 2008; Barredo and Ramos, 2010; Barrdo, 2012). This occurred because its initial sedimentation took place in the isolated depocenters of Barreal, Agua de los Pajaritos and Rincón Blanco and because tertiary compressive deformation produced differential folding of the filling with subsequent truncation and superposition of some of the lithostratigraphic units (Barrdo, 2012). Within this context, Barredo

\footnotetext{
* Corresponding author. Instituto y Museo de Ciencias Naturales, Área Paleontología de Vertebrados, Universidad Nacional de San Juan, 5400, San Juan, San Juan, Argentina.

E-mail address: drovandijuan@gmail.com (J.M. Drovandi).
} 


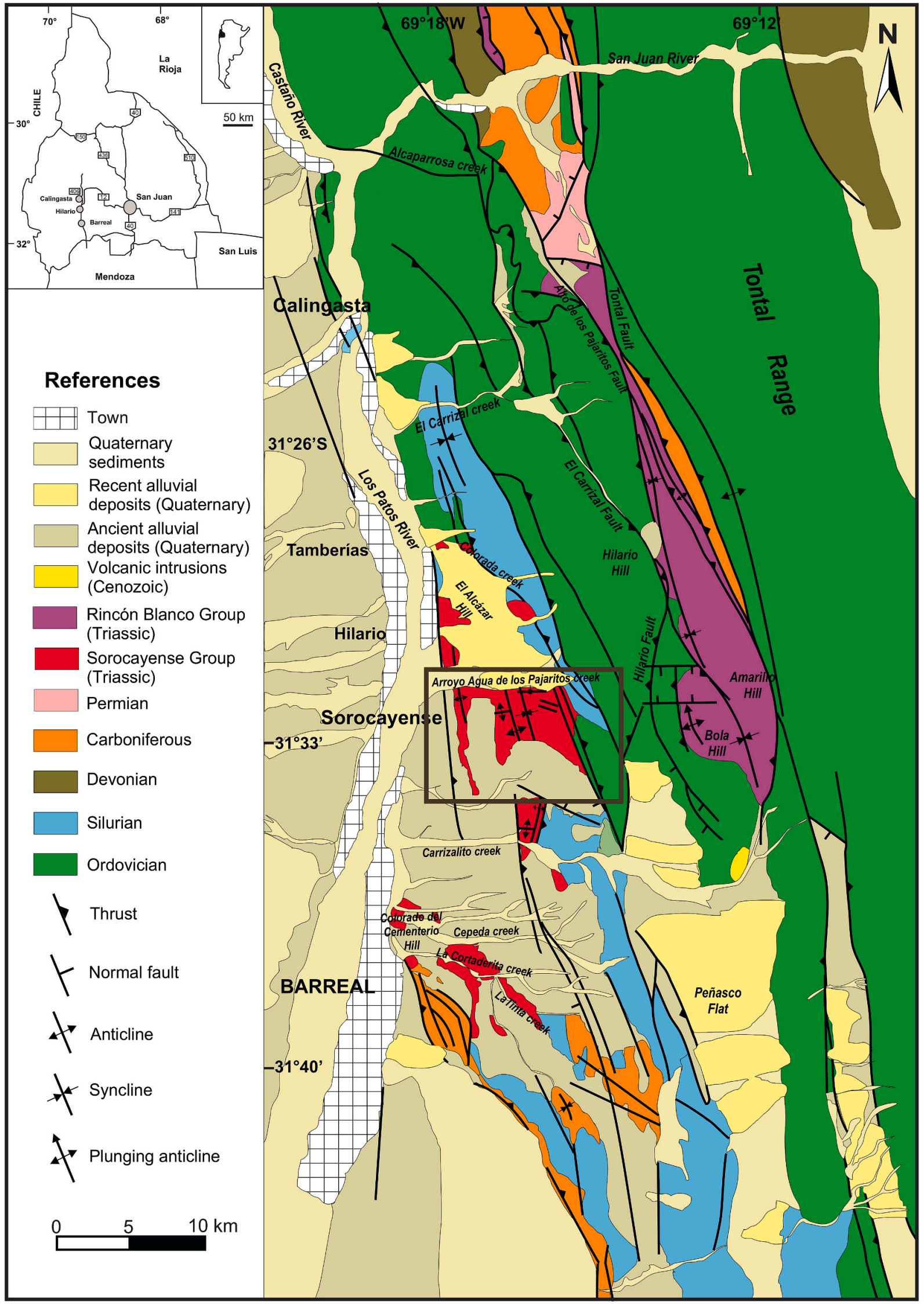

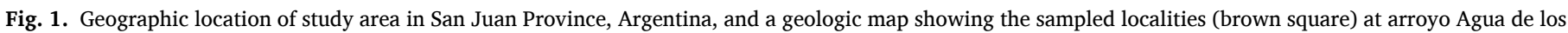
Pajaritos Creek. Redrawn and modified from Barrdo (2012). (For interpretation of the references to colour in this figure legend, the reader is referred to the Web version of this article.) 
et al. (2016) applied tectono-sedimentary concepts in a regional study, to determine that the most consistent stratigraphic scheme for the Triassic sediments in the Agua de los Pajaritos depocenter is that proposed by Baraldo and Guerstein (1984). The Sorocayense Group in the Agua de los Pajaritos depocenter was divided into four formations including, from the base to the top, Agua de los Pajaritos (Stipanicic and Bonetti, 1969), Monina (Baraldo and Guerstein, 1984), Hilario (Stipanicic, 1969), and El Alcázar (Stipanicic, 1969). The latter is the stratigraphic scheme used in this study (Fig. 2). For this depocenter, paleofloristic studies are scarce and are limited to floristic lists for the El Alcázar Formation (Stappenbeck, 1910; Du Toit, 1927a, 1927b; Stipanicic, 1972, 1979) and three articles of systematic descriptions (Menéndez, 1957, 1958; Ganuza et al., 1998).

The main objective of this study is to present the first paleofloristic record for the Monina Formation. These findings will enable us to expand the paleogeographic and temporal distribution of some of the species present in the Sorocayense Group and to provide biostratigraphic correlation with the other Triassic basins of central-west Argentina. Finally, based on the paleofloristic composition and paleoenviromental characteristics, a paleoecological interpretation of the fossiliferous association can be developed.

\section{Materials and methods}

The geological research included analysis of the stratigraphicsedimentological sections of the Monina Formation, delimiting the base and upper contacts. Nine lithofacies were documented (Table 1), and three facies associations (FAs) were identified using the methodology proposed by Miall $(1978,1996)$ and Melchor (2004, 2007). The descriptions were made following the standardized terminology of Font Quer (1982) and Harris (1937). The wood anatomical description follows the terminology of Boureau (1956), Fahn (1990), the International Association of Wood Anatomists (IAWA) Committee (Richter et al., 2004), and Philippe and Bamford (2008).

The preserved material as impressions-compressions was observed using an Olympus SZ30 binocular stereomicroscope and was photographed with a Nikon Coolpix P510 digital camera. In cases requiring mechanical preparation, needles and a microjack-type pneumatic hammer were used. Permineralized fragments of wood were cut in the Petrotomy Laboratory EXAMINA in the transversal, longitudinal radial, and longitudinal tangential cutting planes for mineralogical and anatomical analysis and special preparations. These slides were observed and photographed using a Biotraza XP-607 linear photothermal optical microscope. In addition, trunk surfaces were polished for macroscopic observation under an Olympus SZ30 binocular stereomicroscope. Finally, paleoenviromental characterisation of the paleoflora carrier levels was performed following the criteria of Spicer (1989), Spicer and Parrish (1990) and Gastaldo and Demko (2011).

All of the specimens were deposited in the collection of the "Instituto y Museo de Ciencias Naturales, Universidad Nacional de San Juan" under the acronyms PBSJ. For the wood specimen and PBSJ A, B, C for the slides. Other abbreviations are FA, facies association and FS, fossiliferous strata.

\section{Results}

\subsection{Sedimentological analysis of the Monina Formation}

The most conspicuous deposits of the Monina Formation occur in the Arroyo Agua de los Pajaritos creek, with a total thickness of $130 \mathrm{~m}$. This unit limits is conformable and transitional at its base and top with the Agua de los Pajaritos and Hilario formations, respectively. Considering the lithofacies and architectural differences observed throughout the unit, it was possible to divide the Monina Formation into three facies associations (FA): basal (FA1), middle (FA2), and cuspidal (FA3) (Fig. 3).

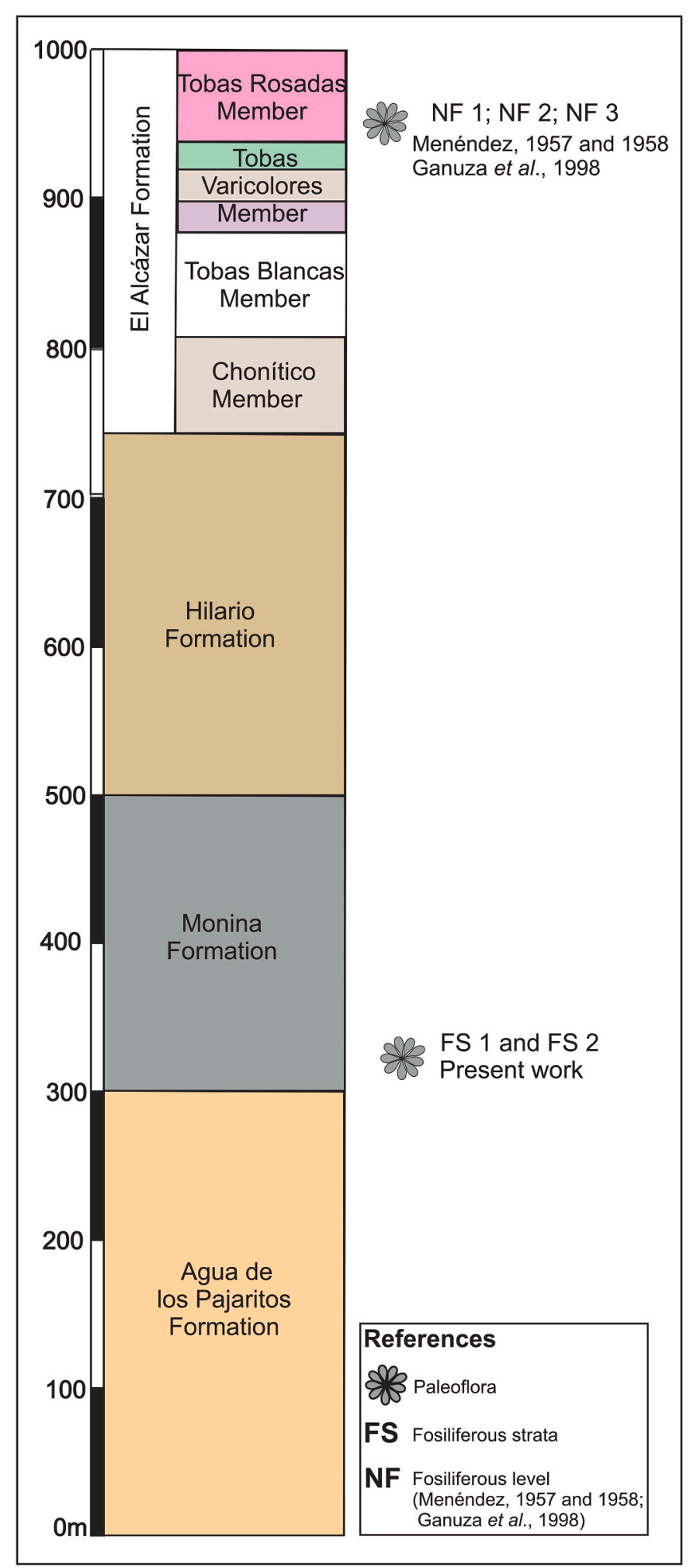

Fig. 2. Schematic stratigraphic column showing the four stratigraphic units of the Agua de los Pajaritos depocenter and the different position of paleo floristic strata from previous work (Menéndez, 1957, 1958; Ganuza et al., 1998) and this contribution.

FA1 has a thickness of $35 \mathrm{~m}$ (Fig. 3) and consists of coarseningupward grain-stratum cycles. Each cycle is characterised by: 1) the presence of fine deposits with laminated and massive structure (Fl/Fsm) 2) tabular geometry that grades from fine to coarse sandstone deposits with cross -bedded and 3) massive structures (St/Sm) and tabular to 
Table 1

Lithofacies code used in this work (modified from Miall, 1996).

\begin{tabular}{|c|c|c|}
\hline Litofacies & Texture & Structure and geometry \\
\hline St & Sandstone & $\begin{array}{l}\text { Crossed stratification in trough. Bodies of lentiform or } \\
\text { tabular geometry. The thicknesses vary between } 0.5 \\
\text { and } 4 \mathrm{~m} \text {. }\end{array}$ \\
\hline Sm & Sandstone & $\begin{array}{l}\text { Massive Bodies of lenticular geometry. Thicknesses } \\
\text { range from } 0.2 \text { to } 4 \mathrm{~m} \text {. }\end{array}$ \\
\hline Sla & Sandstone & $\begin{array}{l}\text { Wave lamination with asymmetric corrugations of low } \\
\text { angle. Tabular geometry body. Thicknesses ranging } \\
\text { from } 1 \text { to } 4 \mathrm{~m} \text {. }\end{array}$ \\
\hline $\operatorname{Tl}(\mathrm{P})$ & Primary Tuff & $\begin{array}{l}\text { Horizontal lamination. Tabular bodies with slightly } \\
\text { concave base. Thickness between } 1 \text { and } 3 \mathrm{~m} \text {. }\end{array}$ \\
\hline $\operatorname{Tt}(\mathrm{P})$ & Primary Tuff & $\begin{array}{l}\text { Structure crisscrossed in trough. Tabular bodies. } \\
\text { Thicknesses ranging from } 1 \text { to } 4 \mathrm{~m} \text {. }\end{array}$ \\
\hline $\operatorname{Tt}(S)$ & $\begin{array}{l}\text { Secondary } \\
\text { Tuff }\end{array}$ & $\begin{array}{l}\text { Structure crisscrossed in trough. Tabular bodies. } \\
\text { Thicknesses ranging from } 1 \text { to } 5 \mathrm{~m} \text {. }\end{array}$ \\
\hline Tmq(s) & $\begin{array}{l}\text { Silicified } \\
\text { Tuff }\end{array}$ & $\begin{array}{l}\text { Massive tabular bodies. Thickness between } 0.3 \text { and } 1 \\
\mathrm{~m} .\end{array}$ \\
\hline $\mathrm{Fl}$ & Limestone & $\begin{array}{l}\text { Horizontal lamination. Bodies of tabular geometry. } \\
\text { Thicknesses that vary between } 0.2 \text { and } 4 \mathrm{~m} \text {. }\end{array}$ \\
\hline Fsm & Limestone & $\begin{array}{l}\text { Massive. Tabular bodies. Thickness between } 0.3 \text { and } 1 \\
\mathrm{~m} .\end{array}$ \\
\hline
\end{tabular}

lentiform geometry. Fine deposits from the lower part of the FA1 exhibit abundant bioturbation features and the middle part of FA1 (12 m thick) is characterised by the presence of clinoforms in the sandstone banks and thin beds of silicified tuffs in the pelitic levels (Tmq (S)). Fossiliferous strata (FS) are located in the fine levels of this section; FS1 and FS2 are located $13 \mathrm{~m}$ and $17 \mathrm{~m}$ from the base of the formation (Fig. 3). The upper part of the FA1 has a thickness of $8 \mathrm{~m}$ and it is characterized by deposits of fine granulometry (mudstone and fine-grained tuff) and tuffs, interspersed with fine sandstone beds, marking the top of FA1.

Based on the description of the FA1, facies of delta platform were recognised, due to the coarsening-upward grain-stratum arrangement of the section with the presence of clinoforms in the tabular bodies of the sandstone, which are covered by thin, laminar deposits typical of a Delta topset. These beds are interspersed with vegetated subaerial platform facies with volcaniclastic influence (Jopling, 1963, 1965; Spicer, 1989, Fig. 3). This FA was interpreted as a low-energy Gylbert-type delta system (Jopling, 1963; 1965; Spicer, 1989).

FA2 has a thickness of $67 \mathrm{~m}$ (Fig. 3). Its base is characterised by the presence of primary tuff pyroclastic deposits (Tt $(\mathrm{P}) / \mathrm{Tl}(\mathrm{P}))$ inherited from FA 1 . The FA2 is characterized by sandstone bodies with lentiform geometry and little erosive base, cross structure and massive structure that includes ondulitic lamination at the base (St/Sm/Sla). These levels are interspersed with laminar and massive structure fine-grained bodies (Fl/Fsm) of tabular geometry. This system begins with a transitional volcaniclastic plateau over deltaic deposits of the anterior facies association (FA1), which is the product of large amounts of tuffaceous material flooding the lacustrine-deltaic system (Miall, 1996, Fig. 3). This section is characterised by the presence of sandstone interspersed with mudstone bodies, with heterolitic deposits occasionally occurring. The arrangement of the deposit is finning upward and tends to become thinner towards the upper part. Based on the criteria of Miall (1996) and Melchor (2004, 2007), this section was interpreted as the development of a low-energy meander system.

FA3 has a thickness of approximately $37 \mathrm{~m}$. It consists of beds of fine granulometry with a laminated structure $(\mathrm{Fl} / \mathrm{Fm})$ and tabular geometry, as well as reductive colouring (dark gray/black), and abundant organic matter. These bodies are interspersed with sand beds of volcaniclastic nature with a low-angle cross-structure and a massive trough (Tmq (S)/ $\mathrm{Tt}(\mathrm{S})$ ) of tabular geometry (Fig. 3). The presence of thin laminated mudstone facies represents suspended sub-aquatic deposits, and the dark colour denotes a high percentage of organic matter transformed into kerogen (Zamora et al., 2008; Abarzúa, 2016). These are interspersed with tuffaceous levels, as evidenced by the presence of current structures. The succession described for FA3 based on was interpreted as a shallow lacustrine environment with sporadic volcanic ash fall (Murcia et al., 2013), which is similar to that observed in other units of this type such as the Ischichuca Formation of the Ischigualasto-Villa Unión Basin (Melchor, 2004, 2007; Miralles, 2010).

\subsection{Paleobotanical systematics}

Division Tracheophyta Sinnott ex Cavallier-Smith, T., 1998

Class Lycopodiopsida Bartling, 1830

Order Isoetales Prantl, 1874

Genus Lepacyclotes Emmons emend. Retallack (1997).

Type species: Lepacyclotes circularis Emmons (1856)

Lepacyclotes sp.

\section{Plate I A and B}

Description: This material consists of two isolated sporophylls from the same stratigraphic level. These sporophylls are linguliform with lengths of $0.9-1 \mathrm{~cm}$ and widths of $0.3-0.4 \mathrm{~cm}$ in the distal third and 0.2 $\mathrm{cm}$ at the base. The sporophylls have linear margins, a rounded base, and an obtuse to slightly mucronate apex. A middle line divides the specimens into two equal halves, delimiting the location of sporangia. This area has a length of $0.4 \mathrm{~cm}$ and a width of $0.1 \mathrm{~cm}$, which suggests that is the adaxial face of the sporophyll.

Studied specimens: PBSJ 1191; 1196.

Fossiliferous strata: FS1.

Remarks: The genus Lepacyclotes is used for axes with numerous sporophylls terminating outwardly in triangular points that form a border outside of a circular ridge (Emmons, 1856: p. 333, Kustatscher et al., 2015). Retallack (1997) considered Annalepis as a junior synonym of Lepacyclotes and proposed that Lepacyclotes also be used for the isolated sporophylls. The described specimens can be assigned to the genus Lepacyclotes after Retallack (1997), because although they are isolated, the most relevant characteristics were observed such as sporophylls in the form of 'tongue', a mucronate apex, the slightly triangular distal portion of the lamina, and the presence of a midline delimiting the area of insertion of the sporangia. No evidence of ligule or scar was observed. Although the presence of a midline dividing the sporophyll could be sufficient to assign the specimens to Lepacyclotes zeilleri (Fliche) Retallack (1997) (Moisan and Voigt, 2013) we consider that this feature alone is not enough evidence. In addition, the sporophylls of $L$. zeilleri are twice the size of the material found in the Monina Formation, and their base is slightly expanded. Compared with L. circularis (Emmons) Retallack (1997), the sporophylls of this species are the specimens studied herein, and possess ligule scar, a character that was not observed in the Monina's specimens. The sporophylls assigned to Lepacyclotes ermayinensis (Wang) Retallack (1997) differ in having larger size and a terminal apex with a marked tip. L. convexus (Brik) Retallack (1997) is generally larger, both in length and width, in addition to the presence of ligule and the apical part culminating in the form of "tooth". L. kirchneri Bauer et al. (2015) has a prominent apical process that in the studied specimens do not or were not preserved (Kustatscher et al., 2015). Cariglino et al. (2018) described specimens referred to Lepacyclotes sp. for the Quebrada de los Fósiles Formation. These specimens consist on a partially preserved axis with, at least, two cycles of densely packed helically arranged sporophylls. Compared with the Monina's specimens, these sporophylls are a few millimeters smaller, both wide and length. They present the same characteristics such as tongue-shaped morphology, a mucronate apex, and a strong midline. The sporophylls from the Monina Formation could represent the same taxon as those described for the Quebrada de los Fósiles Formation.

Class Spermatopsida Serbet and Rothwell, 1995 


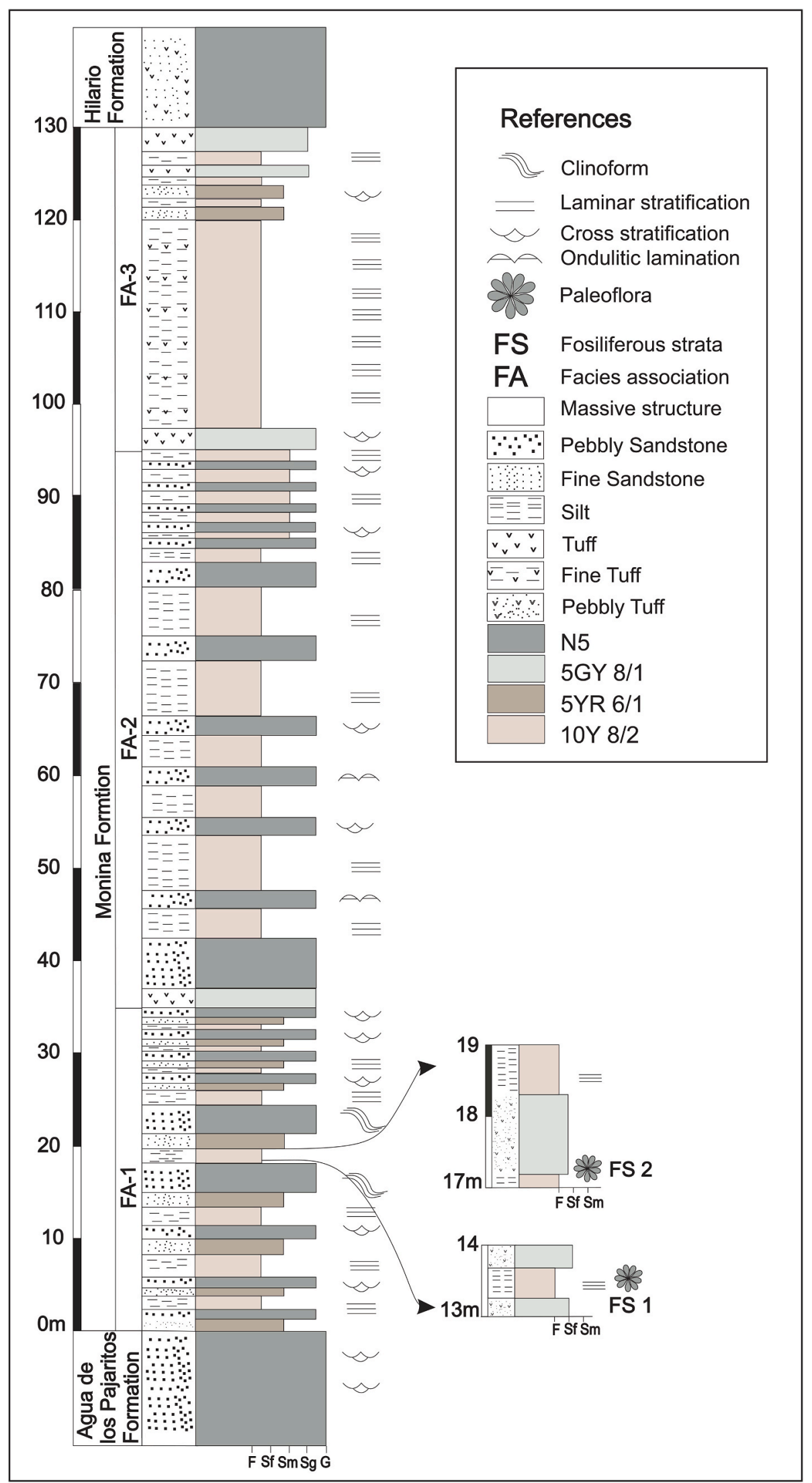

Fig. 3. Sedimentological section of the Monina Formation (Middle Triassic) in Arroyo Agua de los Pajaritos creek showing the stratigraphic distribution of the fossiliferous strata (FS) and the facies association (FA) along the formation. 
Order Peltaspermales Meyen, 1987.

Family Peltaspermaceae Thomas, 1933.

Genus: Scytophyllum Bornemann, 1856.

Type species: Scytophyllum bergi Bornemann (1856).

Scytophyllum sp.

Plate I C

Description: Fragmentary compression of a pinna up to $1.7 \mathrm{~cm}$ long and $1 \mathrm{~cm}$ wide inserted in its most basal part and $0.65 \mathrm{~cm}$ wide in the apical part. The apex was not preserved. The fragment exhibits a linear oblong shape with crenulated margins. The lobes decrease in size towards the apical part, with maximum and minimum widths of $0.5 \mathrm{~cm}$ and $0.3 \mathrm{~cm}$ and maximum and minimum heights of $1.4 \mathrm{~cm}$ and $0.6 \mathrm{~cm}$, respectively. It presents pinnate venation with a conspicuous primary vein from which secondary veins radiate; these are dichotomised before reaching the lobed margin. The midvein reaches the apex. The secondary veins detach opposite to subopposite from the midvein and alternate towards the apex with angles of $62^{\circ}$ in the basal part and $51^{\circ}$ in the apical area before dichotomising near each lobe. Third-order veins can be observed only partially; they radiate from the secondary vein and are dichotomised before reaching the lobe margin.

Studied specimen: PBSJ 1190.

Fossiliferous strata: FS1.

Remarks: Materials assigned to the genus Scytophyllum Bornemann, 1856 have been described in several Triassic Gondwana Basins (e.g. Zamuner and Artabe, 1990; Gnaedinger and Herbst, 1998; Zamuner et al., 1999; Anderson and Anderson, 2003; Morel et al., 2010). The material described for the Monina Formation is comparable in its characteristics with those of the genus Scytophyllum (see Dobruskina, 1969). In particular, the specimen from the Monina Formation exhibits characteristics that are very similar to Scytophyllum bonettiae described by Zamuner et al. (1999) from the Cortaderita Formation (also of the Sorocayense Group, but of the Barreal depocenter). These features include a pinnate pattern of venation with at least three observable vein orders and a crenulated margin. The lobes decrease in size towards the apical part. However, since it is a very fragmentary specimen and the specific characters cannot be observed, we decided not to assign to a specific level the specimen from the Monina Formation. In the Argentinean Triassic, the genus Scytophyllum was described for the Ischigualasto, Cañadón Largo, Cortaderita and El Alcázar formations (Zamuner and Artabe, 1990; Gnaedinger and Herbst, 1998; Zamuner et al., 1999).

Family Matatiellaceae Anderson and Anderson, 2003.

Genus: Matatiella Anderson and Anderson, 2003.

Type species: Matatiella roseta Anderson and Anderson (2003).

Matatiella cf. roseta

Plate I D and E

Description: The specimens appear as discs or disc parts, interpreted as megasporophylls. The section is circular with an average radius of $0.55 \mathrm{~cm}$. They are deeply lobed, with 6 or 7 lobes linked to a central axis. Although the material is poorly preserved, a rib can be seen in the middle part of some lobes. Each lobe is obtriangular in shape with an enlarged and truncated outer margin; in some lobes is preserved a scar that corresponds to the insertion of one ovule per lobe.

Studied specimens: PBSJ 1188; 1189.

Fossiliferous strata: FS1.

Remarks: The material described for the Monina Formation is comparable with the genus Matatiella (Anderson and Anderson, 2003). According to Anderson and Anderson (2003), of all known megasporophylls from the Triassic of Gondwana, Matatiella is comparable to Peltaspermum. However, the difference between both is that Peltaspermum has radial symmetry and Matatiella has bilateral symmetry. In addition to these differences, the material observed in the Monina Formation could be compared with Peltaspermum monodiscum, however, the number of lobes in $P$. monodiscum generally is greater than 10 (11 or 12) and these also have a linear form, unlike Matatiella, where the lobes are obtriangular, and fewer in number. Within the Matatiella genus, the species most similar to our materials is Matatiella roseta, although it has one or two lobes less (Anderson and Anderson, 2003). Because of that characteristic we assigned the specimens of the Monina Formation to M. cf roseta Anderson and Anderson (2003). In the Molteno Formation, three species of similar structure were assigned to Matatiella, M. hemiroseta, M. sessilis and $M$. reducta. M. roseta differs from $M$. hemiroseta, in that the lobes are distributed in a fan-shape on the axis and not as a complete disc. The difference between $M$. sessilis and $M$. reducta with $M$. roseta is in the number of lobes. $M$. sessilis only has four lobes, these are not very prominent, and in some cases aborted ovules are present. $M$. reducta has only 4 lobes deployed, and the only specimen used to describe the species was poorly preserved, so in the opinion of the authors could be a part corresponding to one of the two species previously described. Arce and Lutz (2010) described fossils assignable to Matatiella roseta from Los Rastros Formation, Ischigualasto-Villa Unión Basin. The presence of Matatiella cf. roseta, in the Monina Formation corresponds to the first mention of the species for the Cuyana Basin.

Order Pinales Gorozhankin 1904 (=Coniferales)

Family Podocarpaceae Endlicher 1847.

Genus: Rissikianthus Anderson and Anderson, 2003.

Type species: Rissikianthus townrowii Anderson and Anderson (2003).

\section{cf. Rissikianthus}

Plate I F1 and F2

Description: The specimen consists of an impression of a compact oval lanceolate strobiliform structure connected to a relatively flexible shaft with a width of $0.15 \mathrm{~cm}$. The strobilus has a length of $1.2 \mathrm{~cm}$ and a width of $0.6 \mathrm{~cm}$ at the base; the lengths are $0.75 \mathrm{~cm}$ in the middle part and $0.5 \mathrm{~cm}$ towards the apex. It consists of a woody central axis $0.25 \mathrm{~cm}$ in width bearing helically microsporophylls. A minimum of four microsporophylls are arranged at $90^{\circ}$ in the central axis. Those at the base and the middle part of the strobilus have an average length of $0.2 \mathrm{~cm}$, and those close to the apical part are $0.11 \mathrm{~cm}$ long. Each microsporophyll has a wing in its distal part pointing towards the apex of the strobilus. Owing to the regular level of preservation of the material, the presence of microsporangia linked to the microsporophylls was not verified.

Studied specimens: PBSJ 1195 A and B.

Fossiliferous strata: FS1.

Remarks: The material described for the Monina Formation presents the majority of the characters enunciated by Anderson and Anderson (2003) for the type species of the genus Rissikianthus, as they are compact lanceolate cones and the microsporophylls located on a thick axis with helical arrangement. Anderson and Anderson (2003) described four species of Rissikianthus from the Molteno Formation based on a total of 79 very well-preserved specimens. In addition, similar specimens have been described in the locality of Nymboida, Australia, in the Basin Creek Formation (Holmes and Anderson, 2013). The specimens from the Monina Formation were not assigned to any particular species owing to their poor preservation status. In Argentina, the first mention of specimens assigned to Rissikianthus were Gnaedinger (2010) and Gnaedinger and Herbst (2008); however, the results of these studies lack descriptions and illustrations. Also, Bodnar et al. (2020) released the first description of a pollen cone assigned to Rissikianthus for the Cacheuta 
Formation, Cuyana Basin, Mendoza Province. These authors could not assign the material to a particular species because most of the diagnostic characters were not preserved.

Order Incertae Sedis

Genus: Protocircoporoxylon Vogellehner, 1967.

Type species: Protocircoporoxylon capensis (Walton) Vogellehner (1967).

\section{Protocircoporoxylon sp.}

\section{Plate II A1-A6}

Description: Fragment of a small permineralized woody axis, elliptical in cross section, of $10 \times 12.2 \mathrm{~cm}$ in diameter. The pith is eccentric, with no discernible anatomical detail. Tracheids belonging to the primary xylem are observed around the pith. Homoxylic secondary xylem indistinct or absent growth rings. Tracheids are pentagonal to slightly circular in outline. Tangential diameter of tracheids is 14- (21.7)-33 $\mu \mathrm{m}$, and tracheid walls are 3- (5.13)-7.6 $\mu \mathrm{m}$ thick. Tracheid radial diameter is 16- (19.36)-31 $\mu \mathrm{m}$ and tracheid walls are 3.5- (6)-10 $\mu \mathrm{m}$. Tracheids with mixed radial pitting (sensu Philippe and Bamford, 2008). The bordered pits are uniseriate, rarely opposite or alternate biseriate. The $43 \%$ of the pits is compressed or contiguous, and $56 \%$ is spaced. Pits are 8 - (12)-10.05 $\mu \mathrm{m}$ in radial diameter and 8- (10.75)-14 $\mu \mathrm{m}$ in vertical diameter. Tangential pits are not observed. Cross-fields have 1 or 2 simple circular to oval pits, of circopore type (sensu Philippe, 1995). The cross field pits are $10.6 \times 4.16 \mu \mathrm{m}$ in average diameter. Rays are uniseriate and homocellular, and 1-16 cells in height; with an average height of eigth cells. Ray cells are rectangular (procumbent) with smooth walls. The ray density is 15 per $\mathrm{mm}^{2}$. Axial parenchyma and resin channels are absent.

Studied specimens: PBSJ 1199 A-B-C.

Fossiliferous strata: FS2.

Remarks: The genus Protocircoporoxylon was created by Vogellehner (1967) for fossil woods with araucarian or mixed radial tracheid pitting, and circoporoid crossfields, which means the presence of one or two elliptical oopores (=simple pits) with horizontal major axis. The type species of the genus, P. capensis (Walton) Vogellehner (1967), was described for the South African Triassic. In addition, $P$. mongolense Ding et al., 2011 was reported for the Mongolian Jurassic, and the presence of Protocircoporoxylon was mentioned in the Lower Jurassic of Romania (Philippe et al., 2006) and the Cretaceous of Antarctica (Torres et al., 1997). In Argentina, this genus presents only one species, P. marianaensis Zamuner and Artabe (1994), recorded for the Paso Flores Formation, Upper Triassic, Río Negro Province. Menéndez (1956) described the species Protophyllocladoxylon cortaderitaensis, from the Middle Triassic Cortaderita Formation, San Juan province, Argentina. This taxon was restudied by Vogellehner (1967), who assigned it to his new genus Protocircoporoxylon. More recently, this species was transferred to the corsytosperm genus Rhexoxylon by Bodnar (2008). The fossil wood from Monina Formation presents the diagnostic characters of the genus Protocircoporoxylon, although shows differences with the described species to date. Our specimen shares with $P$. marianensis, the abscence of growth rings and tangential pitting, the presence of exclusively uniseriate rays and up two circopores per cross field. However, $P$. marianensis have most of the cross fields has one circopore, while in the Monina specimen the presence of two circopores per field is very frequent. Also, they differ in the radial and tangential tracheid diameter, since they are larger in $P$. marianensis. The suprageneric systematic affiliation of mesozoic fossil woods with mixed radial tracheid piting and circoporoid cross field, has been discussed by several authors (e.g. Bamford et al., 2016; Bateman and Hilton, 2009). This character combination is observed in different gymnosperm order and families (Grambast, 1952). For example, when the secondary xylem of corystosperms is found isolates, it has the same anatomical features that Protocircoporoxylon. However, the vascular pattern of the corystosperm stems is characterized by the fragmentation of the secondary xylem (Bodnar, 2008), while the Monina specimen shows a compact and undissected wood. Gnaedinger (2007) described several podocarpacean woods from the Jurassic of Argentina, which also have mixed radial trachei pitting and circoporoid cross fields. The wood of Nothophytum krauselii Meyer-Berthaud and Taylor, 1991, from the Antarctic Triassic, is characterized by the mixed tracheid pitting and one or two simple pits in the cross fields, similar to the circopore type. Bomfleur et al. (2013) assigned that species to the voltzialean conifers. By the reason previously exposed, the Monina fossil wood is not associated with a particular order because logs of this type have been assigned to both the Coniferales ( $=$ Pinales) and the Votziales (Bomfleur et al., 2013; Bodnar et al., 2015). This constitutes the oldest record of Protocircopoxylon, and the first mention of the genus for the Cuyana Basin.

\section{Genus: Cordaicarpus Geinitz, 1862}

Type species: Cordaicarpus cordai (Geinitz) Seward, 1917

Cordaicarpus $\mathrm{sp}$

Plate I G

Description: Rounded platyspermic seed, oval with elongated acute apex where the micropile would be located. The specimen is $0.7 \mathrm{~cm}$ wide by $0.62 \mathrm{~cm}$ long. It was possible to differentiate two zones. The external zone corresponds to the sarcotesta and has a uniform width of $0.14 \mathrm{~cm}$; the internal zone, or sclerotesta, has a maximum width of $0.45 \mathrm{~cm}$. The complete micropyle is not visible, nor there is a median ridge or other type of ornamentation in the area of the sclerotesta.

Studied specimen: PBSJ 1192.

Fossiliferous strata: FS1.

Remarks: This material was assigned to the genus Cordaicarpus owing to its platyspermic shape, which is oval at the base and acute towards the micropile area, in addition to the differentiation between the sarcotesta and the sclerotesta. The material was compared with the genus Samaropsis Goeppert 1864, although the dimensions of the sarcotesta are different, and the typical wing of the genus Samaropsis were not observed in the present specimen. Retallack (1980) related seeds assignable to Cordaicarpus with leaves of the genus Linguifolium, a gymnosperm incertae sedis of arboreal habit. Bomfleur et al. (2011) have suggested that both Cordaicarpus and Linguifolium could be related to the Matatiellaceae seed ferns. In Argentina, the genus was found in the Cacheuta, Río Blanco, Llantenes, Paso Flores and Rancho de Lata formations.

\section{Genus: Acevedoa (Arce and Lutz) Arce and Lutz (2014).}

Type species: Acevedoa rastroensis (Arce and Lutz) Arce and Lutz (2014).

\section{Acevedoa cf. rastroensis}

\section{Plate I H1 and H2}

Description: The specimen is a platyspermic seed, oval lanceolate in shape. It has a total length of $0.7 \mathrm{~cm}$ including the micropillar zone and a width of $0.3 \mathrm{~cm}$ in the middle part, which decreases towards both ends. The micropyle area has a width of $0.1 \mathrm{~cm}$ and a length $0.08 \mathrm{~cm}$. A differentiation was observed between the central zone and the periphery of the specimen, which could correspond to the limit between the sarcotesta and sclerotesta.

Studied specimen: PBSJ 1183.

Fossiliferous strata: FS1.

Remarks: The specimen exhibits characteristics that are common to the genus Acevedoa Arce and Lutz, 2014. However, the seed described does not correspond to the genus Samaropsis because it lacks the rounded to sub-rounded shape and thick sarcotesta that characterize that genus. Moreover, is not similar to the genus Cordaicarpus, although 
the shape is similar because lacks the typical notch that this genus presents in the micropile area. Anderson and Anderson (2003) reported specimens that resemble the seed found in the Monina Formation in shape and size, but without a description or systematic affinity. Therefore, the specimens studied are assigned to the genus Acevedoa as characterized by platyspermic seeds without domes or wings; the oval, tapered apex and rounded base; the simple micropile; and the way in which it is curved towards the axis. The material described from the Monina Formation has most of the characters enunciated by Arce and Lutz (2014) for specimens from the Los Rastros Formation. Bomfleur et al. (2011) have suggested that this taxon could have an affinity with the Peltaspermales Order, Matatiellaceae Family, however, since the materials of the Monina Formation were found in the dispersed state, the incertae sedis suprageneric classification was chosen.

\section{Discussion}

\subsection{Paleogeographic and biostratigraphic considerations}

A global floristic change occurred during the Permian-Triassic transition in which some lineages became extinct and others developed to establish the floristic elements during the Mesozoic (Balme and Helby, 1973). Although the biota of the southwest region of Gondwana included taxa common throughout the continent (e.g. Neocalamites, Equisetites, Pleuromeia, Lepidopteris, Baiera, and Sphenobaiera) it was distinguished by the presence of endemic groups such as the Umkomasiaceae (=Corystospermaceae) Family. The Triassic Basins of western Argentina cover a wide temporal spectrum that extends from the Early to Late Triassic and in some cases to the Early Jurassic. This extensive temporal range generated a continuous and abundant paleofloristic record throughout the Triassic (Artabe et al., 1999, 2001; 2003; Morel et al., 2001; Spalletti, 2001; Spalletti et al., 1999; Bodnar et al., 2018).

The paleoflora found in the Monina Formation have systematic importance and also enable us to expand the paleofloristic knowledge of the Cuyana Basin. In addition, they provide tools for establishing biostratigraphic relationships between depocenters within the same basin and within the remaining Triassic basins of north-western Argentina. Moreover, the discovery of paleoflora in the Monina Formation extends the paleobiogeographic distribution of some of the elements described in this study. Sporophylls assigned to the genus Lepacyclotes (Isoetales) have paleobiogeographical importance, because they have a Laurassic affinity (Kustatscher et al., 2010, 2015). In Argentina, they have been registered only in the Quebrada de los Fósiles Formation of the Puesto Viejo Group (San Rafael depocenter, Mendoza Province) and are dated as Middle Triassic (Ottone et al., 2014; Coturel et al., 2016; Cariglino et al., 2018). The presence of Lepacyclotes in the Monina Formation extends its record to the Cuyana Basin, increasing the distribution of this taxon.

The occurrence of the genus Matatiella, has much importance, because this is the first appearance of this structure in the Cuyana Basin. The only record of Matatiella, from Argentina is known from the Ischigualasto-Villa Unión Basin, Los Rastros Formation (Arce and Lutz, 2010), besides the specimens from the Molteno Formation in South Africa (Anderson and Anderson, 2003). That is why Matatiella, has a paleobiogeographical importance as well as temporal implications (Smith et al., 1993; Anderson and Anderson, 2003). The presence of foliar structures assigned to Peltaspermaceae (Scytophyllum) is the first mention of these taxa for the Agua de los Pajaritos depocenter; previously, they were registered in the Cortaderita Formation in the Barreal depocenter (Zamuner et al., 1999, Fig. 1).

The importance of discovering strobiliform structures assigned to the genus Rissikianthus corresponds to the first record of this genus in the San Juan Province. In addition, it expands the biostratigraphic distribution of the genus because materials assignable to Rissikianthus have been mentioned in the Cañadón Largo Formation of the El Tranquilo Group (Gnaedinger, 2010; Gnaedinger and Herbst, 2008) andthe
Cacheuta Formation of the Uspallata Group (Bodnar et al., 2020), both from the Upper Triassic. The presence of permineralized wood assignable to the genus Protocircoporoxylon also extends the paleobiogeographic distribution of the genus to the Cuyana Basin. Previously, it was found in the Paso Flores Formation (Zamuner and Artabe, 1994), corresponding to the Late Triassic (Morel et al., 1999).

The presence of Acevedoa cf. rastroensis in the deposits of the Monina Formation represents the first record of this genus in the Cuyana Basin. Arce and Lutz (2010, 2014) described Acevedoa rastroensis in the Los Rastros Formation (Ischigualasto-Villa Unión Basin) of early Ladinian-Carnian age (Currie et al., 2009; Lutz et al., 2011). Since that time, no other similar structure has been described in the Triassic of Argentina. Therefore, the presence of this taxon in the Monina Formation extends the distribution of this species to the north-western sector of the Cuyana Basin.

\subsection{Paleoenvironmental analysis of the paleofloristic assemblage}

The paleofloristic assemblage of the Monina Formation is at13 m from the base of the unit. It is concentrated in fine facies between tabular sandstone bodies with clinoforms associated with FA1.Two fossiliferous strata comprise the paleofloristic association, the first ( $1 \mathrm{~m}$ thick) corresponds to dark brown laminated facies, intercalated between two white silicified massive tuffaceous beds. This FS1 contains impressions and compressions of conifer reproductive organs conifers, (Rissikianthus sp.), peltasperms (Matatiella), incertae sedis seeds (Cordaicarpus and Acevedoa cf. rastroensis), isolated sporophylls of lycophytes (Lepacyclotes), and an apical leaf fragment of Scytophyllum sp (Plate I A-H).

FS2 is composed of permineralized woody remains of trunks and possible roots fragments attributed to the genus Protocircoporoxylon, and debris with no recognisable taxonomic affiliation (Plate II A). This stratum is located $1 \mathrm{~m}$ above FS1 and consists of a laminated pelitic-silty bed $40 \mathrm{~cm}$ in thickness which is covered by a fine ash layer $70 \mathrm{~cm}$ in thickness. The pelitic layer is disturbed by the woody roots of the trunks, whereas their aerial parts are buried inside the fine ash bed. This deposit is covered by laminar pelitic levels with remnants of unidentifiable fossil remains.

As previously stated, all fossiliferous strata are linked to a low-energy Gylbert-type delta system (Jopling, 1963, 1965; Spicer, 1989). According to Spicer (1989) and Spicer and Parrish (1990), these systems have two spatially separate but synchronous fossiliferous strata: one located in the bottomset and one in the topset of the delta. The deposits located in the bottomset are characterised by the presence of vegetal remains including leaves and mosses that represent high velocity of settlement in addition to biotic-type degradation such as skeletonisation originating from the riparian zones of the lake. The deposits corresponding to the topset are characterised by the presence of paleofloristic remains that travel as bedload. They are deposited in the upper part of the delta because the energy of the current that transported them was insufficient for overcoming the delta slope. These remains, including cones, megasporophylls, and seeds, are of carpological nature and show typical breaks generated by mechanical degradation originating from communities located upstream (Gee, 2005).

In this context, FS1 has the characteristics mentioned by Spicer (1989) for topset deposits of low-energy Gylbert-type deltas which are concordant with the sedimentological characteristics. They are in thin levels that truncate above the deposits with characteristic clinoforms of the delta front. In addition, the association found in the FS1 is composed of materials of a carpological nature such as seeds, cones, and megasporophylls as well as remnants of mechanically fragmented leaves. This interpretation indicates a possibly para-autochthonous origin for the paleofloristic association preserved in FS1.

FS2, however, presents elements that would have grown on a vegetated subaerial platform close to the riparian zones of the lake, as indicated by the remains of trunks with roots associated. This indicates an autochthonous origin for the fossiliferous association. Strikingly, the 


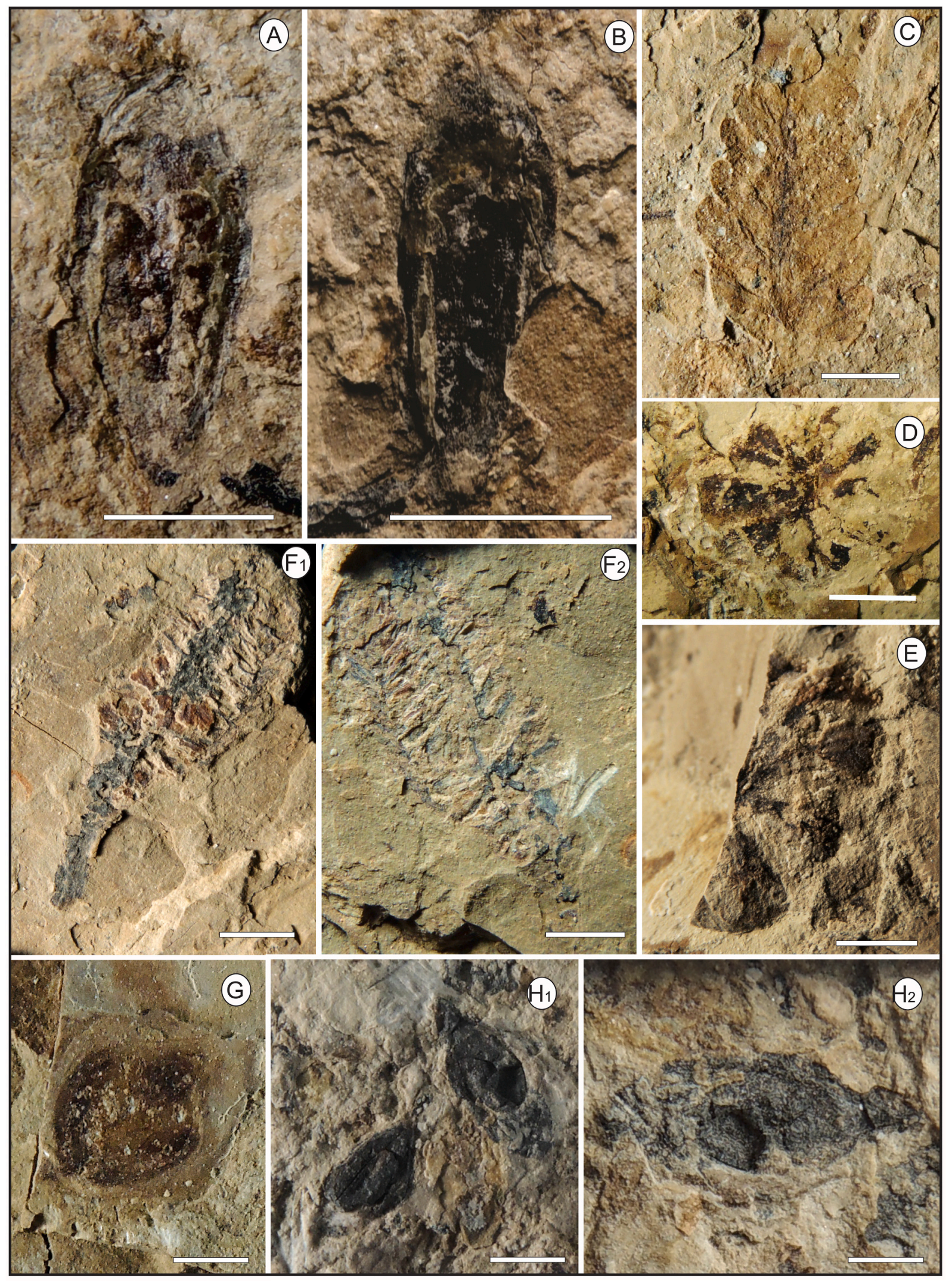

Plate I. A and B. Lepacyclotes (Emmons) Retallack (1997); C. Scytophyllum sp. Bornemann (1856); D and E. Matatiella cf. roseta Anderson and Anderson (2003); $\mathrm{F}_{1}$ and $\mathrm{F}_{2}$. Impression and counterpart of Cf. Rissikianthus Anderson and Anderson, 2003; G. Cordaicarpus Geinitz, 1862; $\mathrm{H}_{1}$ and $\mathrm{H}_{2}$. Acevedoa cf. rastroensis (Arce and Lutz) Arce and Lutz (2014). A to F scale bar: $0,5 \mathrm{~cm}$. G and H scale bar $0,25 \mathrm{~cm}$. 


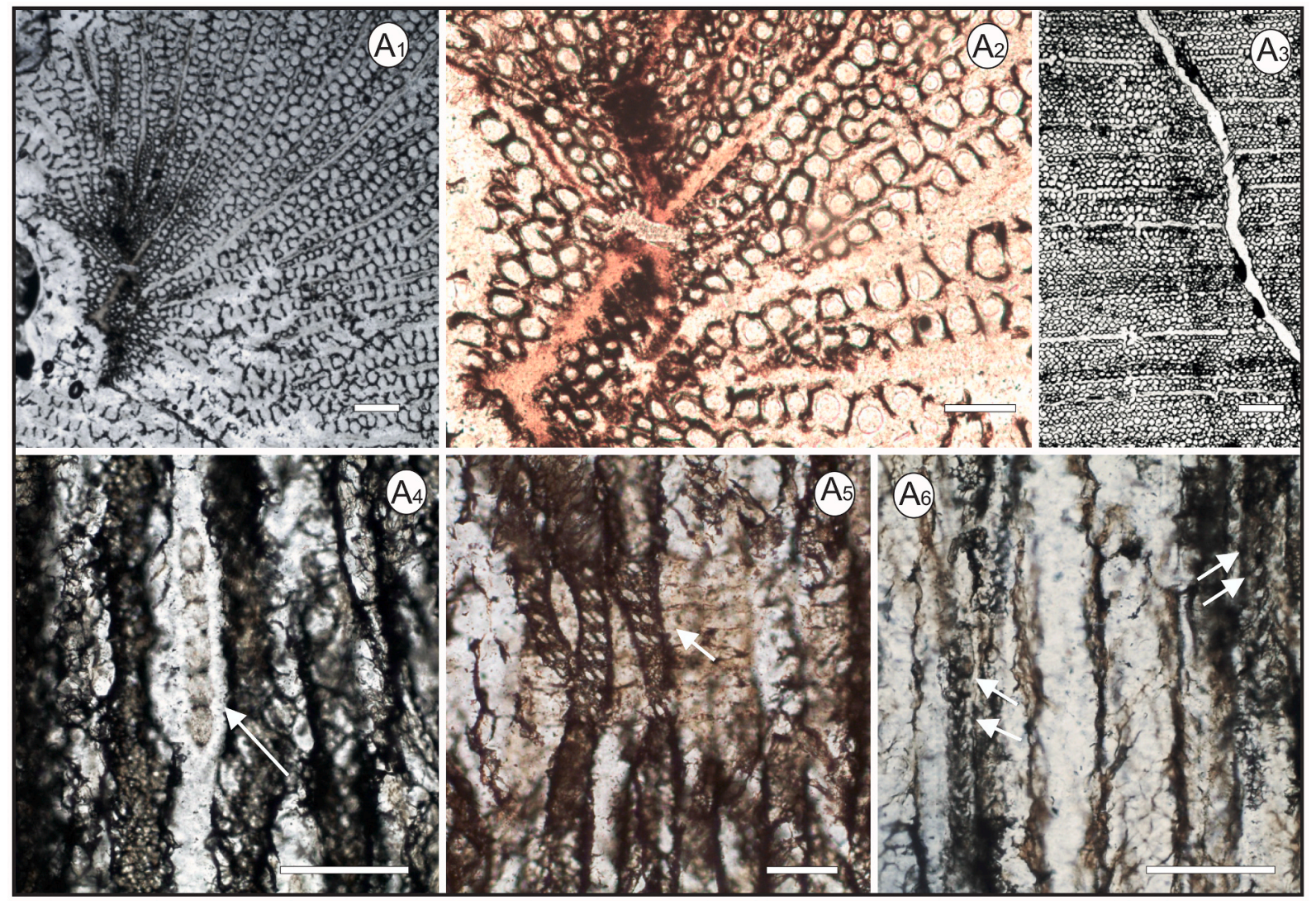

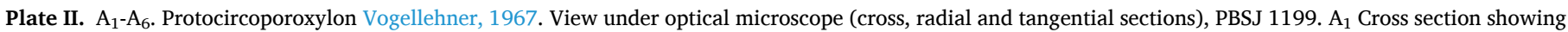

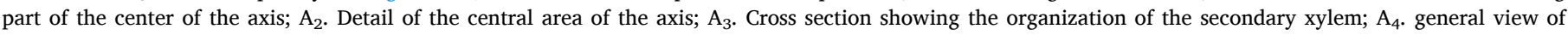

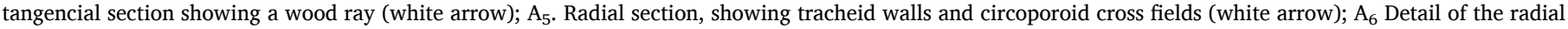
section showing mixed tracheid pits (white arrows). $A_{1}$ and $A_{3}$ scale bar: $500 \mu \mathrm{m} ; A_{2}$ and $A_{5}$ scale bar: $100 \mu \mathrm{m} ; A_{4}$ and $A_{6}$ scale bar: $50 \mu \mathrm{m}$.

roots disturb a silty level that would have served as a substrate for the trees that grew in the subaerial zone of the delta, whereas the aerial parts of these trees are buried by a bank of pyroclastic nature. This indicates that ash fall caused its final burial and subsequent permineralization (Sigleo, 1978, 1979; Gastaldo and Demko, 2011).

\subsection{Paleoecology}

The Triassic flora of Argentina is characterised by the presence of Pleuromeiales, Equisetales, Marattiales, OsmundalesGleicheniales, Umkomasiales (=Corystospermales), Peltaspermales, Cycadales, Ginkgoales, Voltziales, Pinales (=Coniferales). The attributes of xeromorphic adaptations presented by these floras generally link them to dry and seasonal climates, where they formed monospecific bushes or polyspecific herbaceous shrubs and mixed monospecific forests (Wing and Sues, 1992; Artabe et al., 2001). Within the paleoecological context of the Triassic flora, two paleocommunities within the Monina Formation have been tentatively defined. The first consists of the elements found in the FS1, which were formed by paleofloristic remains corresponding to an herbaceous shrub paleocommunity and are characterised by the presence of Scytophyllum sp, Matatiella cf. roseta, Rissikianthus, and, to a lesser extent, Cordaicarpus sp. This community existed close to shallow bodies of water, as indicated by the presence of lycophytes (Lepacyclotes $\mathrm{sp})$. This would correspond to the riparian flora present upstream, as denoted by its degree of transport represented only by woody elements (Spicer, 1989; Spicer and Parrish, 1990; Gastaldo and Demko, 2011). The second recognised paleocommunity for the Monina Formation is characterised by the elements found in the FS2. This corresponds to a monospecific accumulation of conifers including elements assigned to the genus Protocircoporoxylon (Artabe et al., 2001, 2003). These trees would have grown in the riparian zone of the lake; this shows an autochthonous origin near deltaic deposits (Spicer, 1989; Spicer and Parrish, 1990; Gastaldo and Degges, 2007; Gastaldo and Demko, 2011).

\section{Conclusions}

This study presents an analysis of the FAs constituting the Monina Formation, thus supporting the model proposed by Baraldo and Guerstein (1984) which has been subsequently used in other contributions (Bonati et al., 2008; Zamora et al., 2008; Barrdo, 2012; Barredo et al., 2016; Abarzúa, 2016). The first paleofloristic record of the Monina Formation is represented by few specimens of a, wide variety of taxa. It includes Scytophyllum sp, two reproductive structures (Matatiella sp and cf. Rissikianthus), two seed-types (Cordaicarpus sp and Acevedoa cf. rastroensis), isolated megasporophylls of Isoetales (Lepacyclotes sp), and a permineralized log (Protocircoporoxylon sp).

The discovery of this flora extends the paleobiogeographic distribution of some of the elements recovered from the Monina Formation. The first records of the genus Lepacyclotes for the Cuyana Basin and the Sorocayense Group have been reported. Also, this is the first mention of the genus Matatiella in the Cuyana Basin. The presence of Scytophyllum is the first mention of these structures for the Agua de los Pajaritos depocenter. The discovery of materials assignable to Rissikianthus extends its distribution because previously, similar elements had only been mentioned in the Cañadón Largo Formation of the El Tranquilo Group (Gnaedinger and Herbst, 2008; Gnaedinger, 2010) and in the Cacheuta Formation (Bodnar et al., 2020).The presence of Acevedoa cf. rastroensis expanded the distribution of this genus, which had previously been described only in the Los Rastros Formation in the Ischigualasto- Villa Unión Basin (Arce and Lutz, 2010, 2014). Similarly, the presence of the 
genus Protocircoporoxylon extends its distribution to the Agua de los Pajaritos depocenter; its previous record was limited to the Paso Flores Formation (Zamuner and Artabe, 1994). It is noteworthy that it is constituted the oldest worldwide record of the genus, since Monina Formation is Middle Triassic in age. As a whole, the fossil plant assemblage studied here is quite different to the paleofloras occurring in the same lithostratigraphic group, at Barreal area. From the paleoenviromental analysis of the remains found in the Monina Formation, it was deduced that the preservation characteristics and the type of structure preserved in FS1 correspond to that which Spicer (1989) considered as deposits associated with a low-energy Gylbert-type delta. Under such conditions, the materials agree with topset deposits of para-autochthonous origin. However, the remains preserved in FS2, belong to vegetation that grew in the riparian zones of the lake, possibly in a subaerial (autochthonous) deltaic platform, which was buried by ashfall. Finally, the paleoecological analysis shows that the fossils present in FS1 correspond to elements of the understory that integrated with an herbaceous-shrubby community very close to permanent bodies of water. For FS2, the interpretation of a fossiliferous association could correspond to a paleocommunity corresponding to a group of conifers, which would have developed on the vegetated subaerial platform corresponding to the riparian zones of the lake.

\section{Author Statement}

JUAN M. DROVANDI: Writing - original draft; Review \& Editing; Investigation, GUSTAVO A. CORREA: Validation; Investigation, JOSEFINA BODNAR: Writing - review \& editing; Investigation, CARINA E. COLOMBI: Writing - review \& editing, ELIANA P. COTUREL: Writing review \& editing; Investigation, EDUARDO M. MOREL: Funding acquisition

\section{Declaration of competing interest}

The authors declare that they have no known competing financial interests or personal relationships that could have appeared to influence the work reported in this paper.

\section{Acknowledgements}

We thank to Dr. Silvia Gnaedinger for her comments on cf. Rissikianthus. We are also gratefull to Mrs. Alexandra Elbakyan for her help with the bibliography search. This paper improved significantly due to the remarks and suggestions made by the editor, anonymous reviewer and Dr. E.G. Ottone (Instituto de Estudios Andinos Don Pablo Groeber, Universidad de.Buenos Aires, Argentina). This contribution was supported by two FONCYT projects: "Evolución paleoclimática y tectosedimentaria del Triásico Superior de las cuencas Ischigualasto-Villa Unión y Marayes-El Carrizal. Cambios paleoambientales y su influencia en las bio y tafocenosis" (PICT 2015-2074 to CC), and "Evolución de las megafloras del Triásico- Jurásico en el Centro-Oeste de Argentina: Sistemática, Paleoecología y Bioestratigrafía" (PICT-2014-2751 to JB).

\section{References}

Abarzúa, F., 2016. Estratigrafía, análisis de cuenca y aspectos exploratorios en el extremo norte de Cuenca Cuyana. Precordillera Occidental y Valle de Calingasta. Tesis Doctoral (Unpublished), Facultad de Ciencias Exactas, Físicas y Naturales. Universidad Nacional de San Juan, p. 187.

Arce, F.E., Lutz, A.I., 2010. Fructificaciones de la Formación los Rastros, triásico superior, provincia de San juan, Argentina. Rev. Mex. Ciencias Geol. 27, 32-42.

Arce, F.E., Lutz, A.I., 2014. Acevedoa nom. nov., nombre de reemplazo para Andersonia Arce and Lutz 2010 (Insertae sedis), preocupado por Andersonia R. Br. 1810 (Plantae, Magnoliophyta, Ericaceae). Rev. Mex. Ciencias Geol. 31 (1), 138-139.

Anderson, J.M., Anderson, H.M., 2003. Heyday of gymnosperms: systematics and biodiversity of the Late Triassic Molteno fructifications. Strelitzia 15, 398.

Artabe, A.E., Zamuner, A.B., Ganuza, D.G., Spalletti, L.A., 1995. Novedades en la tafoflora triásica de la quebrada de la Cortaderita, Barreal, Provincia de San Juan, Argentina. II Reunión del triásico del Cono Sur (Bahía Blanca). Actas I 7.
Artabe, A.E., Morel, E.M., Spalletti, L.A., Brea, M., 1999. Paleoambientes sedimentarios y paleoflora asociada en el Triásico Tardío de Malargüe (Mendoza). Rev. Asoc. Geol. Argent. 53, 526-548.

Artabe, A.E., Morel, E.M., Spalletti, L.A., 2001. Paleoecología de las floras triásicas argentinas. En. In: Artabe, A.E., Morel, E.M., Zamuner, A.B. (Eds.), El Sistema Triásico de Argentina. Fundación Museo de La Plata "Francisco Pascasio Moreno", La Plata, pp. 199-225.

Artabe, A.E., Morel, E.M., Spalletti, L.A., 2003. Caracterización de las provincias fitogeográficas triásicas del Gondwana Extratropical. Ameghiniana 40, 387-405.

Balme, B.E., Helby, R.J., 1973. Floral modifications at the Permian-Triassic boundary in Australia. In: Logan, A., Hills, L.V. (Eds.), The Permian and Triassic Systems and Their Mutual Boundary, vol. 2. Canadian Society of Petroleum Geologists, Memoir, pp. 433-444.

Bamford, M., Philippe, M., Thévenard, F., 2016. Long overdue extinction of the Protopinaceae. Rev. Palaeobot. Palynol. 234, 25-30.

Baraldo, J.A., Guerstein, P.G., 1984. Nuevo ordenamiento estratigráfico para el Triásico de Hilario (Calingasta, San Juan). IX Congreso Geológico Argentino (San Carlos de Bariloche), Actas 1, 79-94.

Barrdo, S.P., 2012. Geodynamic and tectonostratigrafic study of a continental rift: the triassic Cuyana Basin, Argentina. In: Tectonics (Sharkov, E. (Ed.), Institute of Geology of Ore Deposits, Petrography, Mineralogy and Geochemistry (IGEM). Russian Academy of Sciences, Moscow, pp. 99-130.

Barredo, S., Abarzúa, F., Banchig, A., 2016. Nueva propuesta estratigráfica para el triásico del depocentro agua de los pajaritos, Precordillera Occidental. Provincia de San Juan. Acta geológica Lilliana 28 (suplemento). III Jornadas de Geología de Precordillera.

Barredo, S., Ramos, V.A., 2010. Características tectónicas y tectosedimentarias del hemigraben Rincón Blanco, Cuenca Cuyana: una síntesis. Revista de la Asociación Geológica Argentina 66 (1-2), 133-145.

Bartling, F.G., 1830. Ordines naturales plantarum, eorumque characteres et affinitates adjecta generum enumeratione. Sumtibus Dieterichianis, Gottingae, p. 498.

Bateman, R.M., Hilton, J., 2009. Palaeobotanical systematics for the phylogenetic age: applying organ-species, form-species and phylogenetic species concepts in a framework of reconstructed fossil and extant whole-plants. Taxon 58, 1254-1280.

Bauer, K., Kustatscher, E., Dütsch, G., Schmeißner, S., Krings, M., van Konijnenburg-van Cittert, J.H.A., 2015. Lepacyclotes kirchneri n. sp. (Isoetales, Isoetaceae) aus dem Unteren Jura von Oberfranken, Deutschland. Berichte der Naturwissenschaftlichen Gesellschaft Bayreuth 27, 429-443.

Bodnar, J., 2008. Rhexoxylon cortaderitaense (Menéndez) comb. nov., a species of permineralized stemsnewly assigned to the Corystospermaceae, from the Triassic of Argentina. Alcheringa 32, 171-190.

Bodnar, J., 2010. La paleoflora triásica de la Formación Cortaderita en la quebrada homónima, Cuenca de Barreal-Calingasta, provincia de San Juan, Argentina. Tesis Doctoral (Unpublished). Facultad de Ciencias Naturales y Museo, Universidad Nacional de La Plata, p. 283.

Bodnar, J., Ruiz, D., Artabe, A.E., Morel, E.M., Ganuza, D.G., 2015. Voltziales y Pinales (=Coniferales) de la Formación Cortaderita (Triásico Medio), Argentina, y su implicancia en la reconstrucción de las coníferas triásicas. Rev. Bras. Palaontol. 18 (1), 141-160.

Bodnar, J., Drovandi, J.M., Morel, E., Ganuza, D.G., 2018. Middle Triassic Dipteridaceae (Gleicheniales, Polypodiopsida) of west-central Argentina and their relation with palaeoclimatic changes. Acta Palaeontol. Pol. 63 (2), 397-416.

Bodnar, J., Iglesias, A., Colombi, C.E., Drovandi, J., 2019. Stratigraphical, sedimentological and palaeofloristic characterization of Sorocayense group (triassic) in barreal area, san juan province, Argentina. Andean Geol. 46, 567-603.

Bodnar, J., Morel, E., Coturel, E., Ganuza, D., 2020. New plant fossil records and biostratigraphic analysis from the Uspallata group (late triassic) at Cacheuta hill, Cuyo basin, west-central Argentina. Geobios 60, 3-27.

Bomfleur, B., Taylor, E.L., Taylor, T.N., Serbet, R., Krings, M., Kerp, H., 2011. Systematics and paleoecology of a new peltaspermalean seed fern from the Triassic polar vegetation of Gondwana. Int. J. Plant Sci. 172 (6), 807-835.

Bomfleur, B., Decombeix, A.L., Escapa, I.H., Schwendemann, A.B., Axsmith, B., 2013. Whole-plant concept and environment reconstruction of a Telemachus conifer (Voltziales) from the Triassic of Antarctica. Int. J. Plant Sci. 174 (3), 425-444.

Borrello, A.V., Cuerda, A.J., 1965. Grupo Rincón Blanco (triásico san juan). Comisión de Investigaciones Científicas, provincia Buenos Aires, Notas 2 (10), 3-20.

Bonati, S., Barredo, S., Zamora Balcarce, G., Cervera, M., Kowloksky, E., 2008. Análisis tectosedimentario preliminar del Grupo Barreal, cierre norte de la Cuenca Cuyana, provincia de San Juan. $7^{\circ}$ Congreso de Exploración y Desarrollo de Hidrocarburos. Trabajos Técnicos 409-420 (Mar del Plata).

Bonetti, M.I.R., 1963. Contribución al conocimiento de la flora fósil de Barreal, departamento de Calingasta (provincia de San Juan). Tesis Doctoral (Unpublished). Facultad de Ciencias Exactas y Naturales, Universidad de Buenos Aires, p. 260.

Bornemann, J., 1856. Uber organische Reste aus der Lettenkohlengruppe Thüringens, Ein Beitrag zurFauna und Flora dieser Formation besonders über fossile Cycadeen, nebst vergleichenden Untersuchungen über die Blattstruktur der jetztweltlichen Cycadeengattungen, p. 85. Leipzig.

Boureau, E., 1956. Anatomie Végétale. Tome 2. Presses Universitaires de France, París, pp. 3-503.

Cariglino, B., Monti, M., Zavattieri, A.M., 2018. A Middle Triassic macroflora from southwestern Gondwana (Mendoza, Argentina) with typical Northern Hemisphere elements: biostratigraphic, palaeogeographic and palaeoenvironmental implications. Rev. Palaeobot. Palynol. 257, 1-18.

Cavallier-Smith, T., 1998. A revised six kingdom system of life. Biol. Rev. 73:, 203-266. 
Coturel, E.P., Morel, E.M., Ganuza, D., 2016. Lycopodiopsids and equisetopsids from the Triassic of Quebrada de los Fósiles Formation, San Rafael Basin, Argentina. Geobios 49 (3), 167-176.

Currie, B.S., Colombi, C.E., Tabor, N.J., Shipman, T.C., Montañez, I.P., 2009. Stratigraphy and architecture of the upper triassic Ischigualasto formation, Ischigualasto provincial park, san juan, Argentina. J. S. Am. Earth Sci. 27 (1), 74-87.

Ding, Q.H., Fu, X.P., Li, Y., Zhang, W., 2011. New species of Late Mesozoic fossil woods from southeastern Mongolia (in Chinese with English abstract). Glob. Geol. 14 (2), 59-66.

Dobruskina, I.A., 1969. Genus Scytophyllum (the morphology, epidermic texture and systematic position). - Transactions Academy of Sciences of the USSR 190, 35-58.

Du Toit, A.L., 1927a. A geological comparison of South America with South Africa. Carnegie Institution, Publication 381, pp. 1-150.

Du Toit, A.L., 1927b. The fossil flora of the Upper Karroo Beds. Annals of the South African Museum 22, 289-418.

Emmons, E., 1856. Geological Report of the Midland Counties of North Carolina. George Putnam, Raleigh, NC, p. 1857.

Endlicher, S.L., 1847. Synopsis Coniferarum. Scheitlin und Zollikofer, Sangalli (Sankt Gallen).

Fahn, A., 1990. Plant Anatomy. Pergamon Press, Oxford, p. 588.

Font Quer, P., 1982. Iniciación a la botánica. Morfología externa. Fontalba. Barcelona.

Frenguelli, J., 1948. Estratigrafía y edad del llamado Rético en la Argentina. Anales de la Sociedad Argentina de Estudios Geográficos, GAEA 8, 159-309.

Ganuza, D.G., Zamuner, A.B., Artabe, A.E., Spalletti, L.A., 1998. Sistemática y Paleoecología de la Flora triásica de Hilario-Agua de Los Pajaritos (formación el alcázar), provincia de San juan, Argentina. Ameghiniana 35, 271-283.

Gastaldo, R.A., Degges, C.W., 2007. Sedimentology and paleontology of a Carboniferous log jam. Int. J. Coal Geol. 69 (1-2), 103-118.

Gastaldo, R.A., Demko, T.M., 2011. The relationship between continental landscape evolution and the plant-fossil record: long term hydrologic controls on preservation. In: Taphonomy. Springer, Dordrecht, pp. 249-285.

Geinitz, H.B., 1862. Dyas oder die Zechsteinformation und das Rothliegende, II, Die Pflanzen der Dyas und Geologisches. W. Engelmann, Leipzig, p. 342.

Gee, C.T., 2005. The genesis of mass carpological deposits (bedload carpodeposits) in the Tertiary of the Lower Rhine Basin, Germany. Palaios 20 (5), 463-478.

Gnaedinger, S., Herbst, R., 1998. La flora triásica del Grupo El Tranquilo, provincia de Santa Cruz (Patagonia). Parte IV. Pteridospermae. Ameghiniana 35, 33-52.

Gnaedinger, S., Herbst, R., 2008. Listado preliminar de estructuras reproductivas del Grupo El Tranquilo, Triásico Superior, Santa Cruz, Argentina. Reunión Comunicaciones Científicas y Tecnológicas. Universidad Nacional del Nordeste, Corrientes, Argentina. B28.

Gnaedinger, S., 2007. Planoxylon Stopes, Protelicoxylon Philippe y Herbstiloxylon nov. gen.(Coniferales) de la Formación La Matilde (Jurásico Medio), provincia de Santa Cruz, Argentina. Ameghiniana 44 (2), 321-335.

Gnaedinger, S., 2010. Estructuras reproductivas en el Grupo El Tranquilo (Triásico tardío), provincia de Santa Cruz, Argentina. In: X Congreso Argentino de Paleontología y Bioestratigrafía-VII Congreso Latinoamericano de Paleontología.

Goeppert, H.R., 1864. Die fossile Flora der Permischen Formation. Paleontographica, Abt. B 12, Stuttgart, pp. 1-224.

Gorozhankin, I.N., 1904. Lekcii Po Morfologii I Sistematiki Arhegonial'nyh Rastenij. II. Pteridophyta. Mamontov, Moscow.

Grambast, L., 1952. Sur la signification des structures généralisées chez les coniférales et la valeur des Protopinacées en tant que groupe. C.R. Acad. Sci. Paris 235, 1533-1535.

Groeber, P., Stipanicic, P., 1953. Mesozoico. Geografía de la República Argentina. Sociedad Argentina de Estudios Geográficos. In: Triásico En Groeber, P., Stipanicic, P., Mingramm, A. (Eds.), vol. 2 (1), pp. 13-141.

Harris, T.M., 1937. The fossil flora of Scoresby Sound East Greenland. Part 5: stratigraphic relations of the plant beds. Meddelelser om Grønland 112, 1-114.

Holmes, W.B.K., Anderson, H.M., 2013. The middle triassic megafossil flora of the Basin Creek Formation, Nymboida coal measures, new south wales, Australia. Part 9. The genera heidiphyllum, voltziopsis, rissikia and affiliated cones and yabiella. Proc. Linn. Soc. N. S. W. 135, 55-76.

Jopling, A.V., 1963. Hydraulic studies on the origin of bedding. Sedimentology 2 (2), $115-121$.

Jopling, A.V., 1965. Hydraulic factors controlling the shape of laminae in laboratory deltas. J. Sediment. Res. 35 (4), 777-791.

Kustatscher, E., Wachtler, M., and Van Konijnenburg-Van Cittert, J H. 2010. Lycophytes from the middle triassic (anisian) locality kanduuml; hwiesenkopf (monte pragrave; della Vacca) in the dolomites (northern Italy).

Kustatscher, E., Donà, H., Krings, M., 2015. Sporophyll organization in the Triassic isoetalean lycopsid Lepacyclotes (formerly Annalepis) zeilleri from Germany. Paläontol. Z. 89 (3), 303-311.

López Gamundí, O., 1994. Facies distribution in an asymmetric half-graben: the northern Cuyo Basin (Triassic), western Argentina. In: XIV International Sedimentological Congress (Recife). Abstracts, pp. 6-7.

Lutz, A., Gnaedinger, S., Mancuso, A., Crisafulli, A., 2011. Paleoflora de la Formación los Rastros (triásico medio), provincia de San juan, Argentina. Consideraciones taxonómicas y tafonómicas. Ameghiniana 48 (4), 568-588.

Menéndez, C.A., 1956. Protophyllocladoxylon cortaderitaensis sp. nov. Tronco fósil del Triásico de Barreal (provincia de San Juan). Revista de la Asociación Geológica Argentina 11, 273-280.

Menéndez, C.A., 1957. Asterotheca hilariensis sp. nov. del Triásico superior de Hilario, San Juan. Ameghiniana 1 (1-2), 25-32.

Menéndez, C.A., 1958. Equisetites quindecimdentata sp. nov. del Triasico superior de Hilario, San Juan. Rev. Asoc. Geol. Argent. 13 (1), 5-14.
Melchor, R.N., 2004. Trace fossil distribution in lacustrine deltas: examples from the Triassic rift lakes of the Ischigualasto-Villa Unión Basin, Argentina. Geological Society, London, Special Publications 228 (1), 335-354.

Melchor, R.N., 2007. Changing lake dynamics and sequence stratigraphy of synrift lacustrine strata in a half-graben: an example from the Triassic Ischigualasto-Villa Unión Basin, Argentina. Sedimentology 54 (6), 1417-1446.

Mésigos, M.G., 1953. El Paleozoico Superior de Barreal y su continuación austral, Sierra de Barreal, Provincia de San Juan. Rev. Asoc. Geol. Argent. 8, 65-109.

Meyen, S.V., 1987. Fundamentals of Palaeobotany. Chapman and Hall, Londres, p. 432.

Meyer-Berthaud, B., Taylor, T.N., 1991. A probable conifer with podocarpacean affinities from the Triassic of Antarctica. Review of Palaeobotany and Palynology 67 (3-4), $179-198$.

Miall, A.D., 1978. Lithofacies types and vertical profile models in braided rivers: a summary. In: Miall, A.D. (Ed.), Fluvial Sedimentology, vol. 5. Canadian Society of Petroleum Geology, Memoir, pp. 597-604.

Miall, A.D., 1996. The Geology of Fluvial Deposits. Sedimentary Facies, Basin Analysis, and Petroleum Geology. Springer eds., New York, p. 582.

Miralles, A.A., 2010. Sedimentología: del proceso físico a la cuenca sedimentaria. Editorial CSIC-CSIC Press Vol. 46.

Moisan, P., Voigt, S., 2013. Lycopsids from the madygen lagerstätte (middle to late triassic, Kyrgyzstan, central asia). Rev. Palaeobot. Palynol. 192, 42-64.

Morel, E.M., Artabe, A.E., Ganuza, D., Zúñiga, A., 2010. La paleoflora triásica del cerro Cacheuta, provincia de Mendoza, Argentina. Bryopsida, Lycopsida, Sphenopsida, Filicopsida y Gymnospermopsida (Corystospermales y Peltaspermales). Ameghiniana 47, 3-23.

Morel, E.M., Artabe, A.E., Zavattieri, A.M., Bonaparte, J., 2001. Cronología del Triásico de Argentina. In: Artabe, A.E., Morel, E.M., Zamuner, A.B. (Eds.), El Sistema Triásico de Argentina. Fundación Museo de La Plata "Francisco Pascasio Moreno", La Plata, pp. 227-253. En.

Morel, E.M, Ganuza, D.G., Zúñiga, A., 1999. Revisión paleoflorística de la Formación Paso Flores, Triásico superior de Río Negro y del Neuquén. Revista de la Asociación Geológica Argentina 54 (4), 389-406.

Murcia, H.F., Borrero, C.A., Pardo, N., Alvarado, G.E., Arnosio, M., Scolamacchia, T., 2013. Depósitos volcaniclásticos: Términos y conceptos para una clasificación en español. Rev. Geol. Am. Cent. 48 (48), 15-39.

Ottone, E.G., Monti, M., Marsicano, C.A., de la Fuente, M.S., Naipauer, M., Armstrong, R., Mancuso, A.C., 2014. A new Late Triassic age for the Puesto Viejo Group (San Rafael depocenter, Argentina): SHRIMP U-Pb zircon dating and biostratigraphic correlations across southern Gondwana. J. S. Am. Earth Sci. 56, 186-199.

Philippe, M., 1995. Reappraisal of five genera designed for fossil coniferous woods by early American wood anatomists. IAWA Journal 23, 319-326.

Philippe, M., Bamford, M.K., 2008. A key to morphogenera used for Mesozoic coniferlike woods. Rev. Palaeobot. Palynol. 148 (2-4), 184-207.

Philippe, M., Barbacka, M., Gradinaru, E., Iamendei, E., Iamandei, S., Kázmér, M., Popa, M., Szakmány, G., Tchoumatchenco, P., Zaton, M., 2006. Fossil wood and mideastern europe terrestrial palaeobiogeography during the jurassic-early cretaceous interval. Rev. Palaeobot. Palynol. 142 (1), 15-32.

Prantl, K., 1874. Lehrbuch der Botanik. Engelmann, Leipzig, p. 240.

Pozzo, A., 1948. Estudio geológico, estratigráfico y tectónico de la Precordillera, al este del río de los Patos y al sud de Calingasta (Provincia de San Juan). Tesis doctoral, Facultad de Ciencias Exactas, Físicas y Naturales. Universidad de Buenos Aires, p. 101, 12 láms, 3 perf., mapa. Inédito.

Ramos, V.A., Kay, S.M., 1991. Triassic rifting and associated basalts in the Cuyo Basin, central Argentina. In: Andean Magmatism and its Tectonic Setting, vol. 265. Geological Society of America, Boulder, pp. 79-191.

Retallack, G.J., 1980. Late carboniferous to middle triassic megafossil floras from the sydney basin. In: A Guide to the Sydney Basin. Bulletin of the Geological Survey New South Wales, vol. 26, pp. 385-430.

Retallack, G.J., 1997. Earliest Triassic origin of Isoetes and quillwort evolutionary radiation. J. Paleontol. 71, 500-521.

Richter, H.G., Grosser, D., Heinz, I., Gasson, P.E., 2004. IAWA list of microscopic features for softwood identification. Iawa Journal 25 (1), 1-70.

Rolleri, E.O., Criado Roque, P., 1968. La cuenca triásica del norte de Mendoza. Jornadas Geológicas Argentinas 3, 1-76.

Serbet, R., Rothwell, G.W., 1995. Functional morphology and homologies of gymnospermous ovules: Evidence from a new species of Stephanospermum (Medullosales). Canadian Journal of Botany 73, 650-661.

Seward, A.C., 1917. Fossil Plants, Volumen III, p. 650 pp. Cambridge University Press.

Sigleo, A.C., 1978. Organic geochemistry of silicified wood, petrified forest national park, Arizona. Geochem. Cosmochim. Acta 42 (9), 1397-1405.

Sigleo, A.C., 1979. Geochemistry of silicified wood and associated sediments, petrified forest national park, Arizona. Chem. Geol. 26 (1-2), 151-163.

Smith, R.M.H., Eriksson, P.G., Botha, W.J., 1993. A review of the stratigraphy and sedimentary environments of the Karoo-aged Basins of Southern Africa. J. Afr. Earth Sci. 16 (1-2), 143-169.

Spalletti, Luis A., 1997. Cuencas triásicas del oeste argentino: origen y evolución. Acta Geol. Hisp. 32 (1), 29-50.

Spalletti, L.A., 2001. Modelo de sedimentación fluvial y lacustre en el margen pasivo de un hemigraben: el Triásico de la Precordillera Occidental de San Juan, República Argentina. Rev. Asoc. Geol. Argent. 56, 189-210.

Spalletti, L.A., Artabe, A.E., Morel, E.M., Brea, M., 1999. Biozonación paleoflorística y cronoestratigrafía del Triásico Argentino. Ameghiniana 36, 419-451.

Spicer, R.A., 1989. The formation and interpretation of plant fossil assemblages. In: Advances in Botanical Research, vol. 16. Academic Press, pp. 95-191. 
Spicer, R.A., Parrish, J.T., 1990. Late Cretaceous-early Tertiary palaeoclimates of northern high latitudes: a quantitative view. J. Geol. Soc. 147 (2), 329-341.

Stipanicic, P.N., Bonetti, M.I.R, 1969. Consideraciones sobre la cronología de los terrenos triásicos argentinos. I Simposio Internacional Estratigrafía y Paleontología del Gondwana, Mar del Plata. UNESCO, Ciencias de la Tierra 2, 1081-1120. Paris.

Stipanicic, P.N., Menéndez, C.A., 1949. Contribución al conocimiento de la flora fósil de Barreal (provincia de San Juan). I. Dipteridaceae, vol. 24. Boletín de Informaciones Petroleras, Buenos Aires, pp. 44-73.

Stipanicic, P.N., Bonetti, M.I.R., 1965. Las especies del género Saportaea del Triásico de Barreal (San Juan). Revista del Museo Argentino de Ciencias Naturales "Bernardino Rivadavia". Paleontología 1, 81-114.

Stappenbeck, R., 1910. La Precordillera de San Juan y Mendoza. Anales del Ministerio de Agricultura de la Nación, Sección Geología, Mineralogía y Minería 4, 3-187.

Stipanicic, P.N., 1969. Las sucesiones triásicas argentinas. I Coloquio de la UICG: La estratigrafía del Gondwana. UNESCO, Ciencias de la Tierra 2, 1121-1149. Buenos Aires.

Stipanicic, P.N., 1972. Cuenca triásica de Barreal. In: Leanza, A.F. (Ed.), Geología Regional Argentina. Academia Nacional de Ciencias, Córdoba, pp. 537-566. En.

Stipanicic, P.N., 1979. El Triásico del valle del Río de Los Patos (provincia de San Juan). In: Turner, J.C.M. (Ed.), Geología Regional Argentina. Academia Nacional de Ciencias, Córdoba, pp. 695-744. En.

Stipanicic, P.N., Zavattieri, A., 2002. Triásico. En stipanicic. In: P, N., Marsicano, C.A. (Eds.), Léxico Estratigráfico de la Argentina, vol. 8, p. 870 (Buenos Aires).

Thomas, H.H., 1933. On some pteridospermous plants from the mesozoic rocks of South Africa. Phil. Trans. Biol. Sci. 222, 193-265.

Torres, T., Barale, G., Méon, H., Philippe, M., Thévenard, F., 1997. Cretaceous floras from snow island (south shetland islands, Antarctica) and their biostratigraphic significance. In: Ricci, C.A. (Ed.), The Antarctic Region: Geological Evolution and Processes. Terra Antarctica Publication Siena, pp. 1023-1028.

Uliana, M.A., Biddle, K.T., Cerdan, J., 1989. Mesozoic Extension and the Formation of Argentine Sedimentary Basins. Analogs (Chapter 39).

Vogellehner, D., 1967. Zur Anatomie und Phylogenie mesozoischer

Gymnospermenhölzer, 5: prodromus zu einer Monographie der Protopinaceae. I. Die protopinoiden Hölzer der Trias. Palaeontograph. Abteilung B 30-51.

Wing, S., Sues, H.D., 1992. Mesozoic and early cenozoic terrestrial ecosystems. In: Behrensmeyer, A., Damuth, J., DiMichele, W., Potts, R., Sues, H.D., Wing, S. (Eds.), Terrestrial Ecosystems through Time: Evolutionary Paleoecology of Terrestrial Plants and Animals. The University of Chicago Press, pp. 327-416.

Yrigoyen, M.R., Stover, L.E., 1970. La palinología como elemento de correlación del Triásico en la Cuenca Cuyana. Cuartas Jornadas Geológicas Argentinas (Mendoza), Actas 2, 427-447.

Zamora, G., Cervera, M., Barredo, S., 2008. Geología y potential Petrolero de un bolsón intermontano: bloque Lamberías, Provincia de San Juan. In: VI Congreso de Exploración y Desarrollo de Hidrocarburos. Actas, Mar de Plata, pp. 397-408.

Zamuner, A.B., Artabe, A.E., 1990. El género Scytophyllum Bornemann 1856 (Familia Peltaspermaceae Thomas), un nuevo representante de la flora Triásica de Argentina. Rev. Mus. La Plata 9 (54), 131-141.

Zamuner, A.B., Artabe, A.E., 1994. Estudio de un leño fósil, Protocircoporoxylon marianaensis n. sp., de la Formación Paso Flores (Neotriásico), provincia de Río Negro, Argentina. Ameghiniana 31 (3), 203-207.

Zamuner, A.B., Artabe, A.E., Ganuza, D.G., 1999. A new peltasperm (gymnospermopsida) from the middle triassic of Argentina. Alcheringa 23, 185-191. 